\title{
MATHEMATICAL ABILITY ANALYSIS BASED ON ASSIST SCALE WITH A DIFFERENT LEARNING APPROACH TO PREPARE A PROFESSIONAL TEACHER CANDIDATE IN DEALING WITH ASEAN ECONOMIC COMUNITY (AEC)
}

\author{
Dame Ifa Sihombing1, Agusmanto Hutauruk ${ }^{2}$, Ismail Husein ${ }^{3}$ \\ 1,2Department of Mathematic Education \\ ${ }^{3}$ Department of Mathematics \\ HKBP Nommensen of University \\ UINSU Medan \\ sihombingdame@gmail.com
}

\begin{abstract}
This paper aimed to basic mathematical skills based to the studying approach. To this subject pre detection is a need. One way ANOVA analyzing will show the significant of basic mathematical skill of students by giving different studying approach. Hence, there is correlation within basic mathematical skill to studying approach. Teachers should be able measure basic mathematical by designing model supporting understanding level, critical thinking ability made concept. The sample consisted of all the second semester of mathematical students by random sampling. Approaches and Study Skills Inventory for Students (ASSIST) is used to studying approach, Bayesian Information Criterion (BIC) is used to create group classification. Two Step Cluster Analysis Method divided into three approaches (Strategies, Surface, Deep).
\end{abstract}

Key words : ASSIST, mathematical skills, studying approach

\begin{abstract}
Abstrak. Tujuan dari penelitian ini adalah untuk megetahui kemampuan dasar matematis berdasarkan pendekatan pembelajaran mahasiswa. Dalam rangka menghadapi Masyarakat Ekonomi Asean (MEA) mahasiswa sebagai generasi penerus bangsa dituntut untuk siap menghadapi kondisi ini. Oleh karena itu diperlukan deteksi awal untuk mempersiapkan situasi ini. Analisis ANOVA satu arah akan menunjukkan signifikansi kemampuan dasar matematis diantara mahasiswa yang di berlakukan dengan pendekatan pembelajaran yang berbeda-beda. Terdapat korelasi antara kemampuan dasar matematis dengan pendekatan pembelajaran, dengan mengukur kemampuan mahasiswa para guru harus mampu mendesain model yang
\end{abstract}


mendorong tingkat pemahaman, kemampuan berfikir kritis sehingga mahasiswa memahami konsep. Hasil nya diharapkan dapat memberikan kontribusi dalam bidang pendidikan untuk mempersiapkan calon guru khususnya matematika agar siap dalam kompetensinya sebagai calon pendidik dalam menghadapi MEA. Dengan mengambil sampel seluruh mahasiswa program studi matematika semester 2 di Universitas HKBP Nommensen yang dipilih secara acak dengan metode klaster. Studi Pendekatan ASSIST digunakan sebagai pendekatan pembelajaran, berdasarkan Bayesian Information Criterion (BIC) yang berkaitan dengan skala ASSIST maka mahasiswa tersebut dibentuk dalam tiga grup. Dengan menggunakan analisis metode klaster dua tahap mahasiswa dibagi ke dalam tiga pendekatan yaitu pendekatan strategi, luaran dan mendalam.

\section{Kata kunci: Skala ASSIST, Kemampuan matematis, Pendekatan pembelajaran}

\section{PENDAHULUAN}

Dalam menghadapi era Masyarakat Ekonomi Asean (MEA) sekarang ini dimana mahasiswa berjuang dan belajar sangat bergantung kepada kemajuan IPTEK, komunikasi media elektronik, dan ekonomi global. Lowongan kerja yang memberikan sumbangsih terhadap pergerakan ekonomi pada era MEA ini pun membutuhkan pekerja-pekerja yang siap untuk mengadopsi kemajuan ide-ide yang berkembang pesat, dapat mengikuti pola perkembangan global, dan mampu menyelesaikan masalah-masalah yang cenderung rumit. Matematika merupakan salah satu kunci yang memberikan kesempatan untuk pekerjaan yang sedemikian. Selain banyak nya penerapan ilmu matematika dalam kehidupan sehari-hari dan dalam berbagai profesi, matematika masih menjadi momok dan pelajaran yang rumit bagi kebanyakan orang khususnya pada mahasiswa. Banyak penelitian pendidikan matematika mengindikasi kan bahwa terdapat beberapa faktor yang mempengaruhi tampilan dan hasil penilaian terhadap matematika. Sebuah studi literatur matematika, yaitu konsep diri, kelebihan kemampuan matematika, cara belajar, keingintahuan terhadap matematika dan cara berfikir terhadap matematika telah menunjukkan bahwa variabel-variabel ini berpengaruh terhadap penilaian tentang matematika. 
Pentingnya belajar matematika tidak terlepas dari peranannya dalam berbagai kehidupan, misalnya berbagai informasi dan gagasan banyak dikomunikasikan atau disampaikan dengan bahasa matematis serta banyak masalah kontekstual dapat disajikan ke dalam model matematik. Sesuai dengan pendapat Turmudi (2008:3) bahwa matematika berkaitan erat dengan kehidupan sehari-hari sehingga dengan segera siswa akan mampu menerapkan matematika dalam konteks yang berguna bagi siswa baik dalam kehidupannya ataupun dalam dunia kerja kelak. Selain itu, mempelajari matematika dapat membiasakan seseorang berpikir kritis, logis, serta dapat meningkatkan daya kreativitasnya. Menurut Cockroft( dalam Shadiq, 2004 ) menyatakan bahwa akan sangat sulit atau tidaklah mungkin bagi seseorang untuk hidup dibagian bumi ini pada abad ke 20 tanpa sedikitpun memanfaatkan matematika. Penguasaan materi oleh siswa menjadi suatu keharusan yang tidak bisa ditawar lagi didalam penataan nalar dan pengambilan keputusan pada era persaingan yang semakin kompetitif.

Salah satu variabel yang memungkinkan untuk melihat penilaian terhadap matematika adalah pendekatan pembelajaran. Proses ini mengacu kepada bagaimana seorang pelajar atau mahasiswa tertarik terhadap salah satu objek studi atau jurusan. Ada tiga perbedaan pendekatan dalam belajar 1) pendekatan yang mendalam ditandai dengan adanya ketertarikan untuk bekerja secara konseptual dan di dorong oleh rasa ingin tahu dari dalam. 2) Pendekatan dengan strategi di tandai dengan fokus terhadap pencapaian yang tinggi dan pembelajaran yang sistematis. 3) Pendekatan luaran ditandai dengan keinginan untuk mencapai lulus saja, menghindari beban kerja yang terlalu tinggi, salah memahami apa yang dibutuhkan, dan atau berfikir bahwa yang dibutuhkan hanyalah bukti tertulis. Hasilnya mengindikasikan bahwa pendekatan terhadap luaran sedikit hubungannya dengan kesuksesan pencapaian akademik, dan pendekatan yang mendalam dan pendekatan dengan strategi berpengaruh besar terhadap tingginya tingkat pencapaian akademik. (Diseth \& Martinsen, 2003). Selain itu, konsep-konsep kohesi matematika dikaitkan melalui pendekatan yang mendalam untuk belajar matematika dan hasilnya menunjukkan interpretasi yang berbeda dalam belajar matematika.

Secara statistik, menurunnya minat mahasiswa terhadap matematika adalah hal yang umum pada kebanyakan tingkat akademik. Oleh karena itu, sangatlah penting untuk menyelidiki alasan kegagalan mahasiswa dan perlu juga menentukan 
variabel-variabel apa yang dibutuhkan mahasiswa di dalam pendekatan pembelajaran.Metode pembelajaran individu yang berhasil adalah cara yang sangat berpengaruh untuk menemukan metode terbaik dalam belajar dan pembelajaran. Dengan mengidentifikasi prosedur keberhasilan pembelajaran secara individu dan mengajarkan nya kepada siswa yang lain adalah cara yang sangat efektif untuk mensosialisasikan budaya nasional dan membuktikan kualitas pendidikan.

Saat ini, dengan disahkannya MEA kita tidak ingin terjadi kesenjangan yang membuat guru-guru kita direndahkan di negara sendiri, lebih jauhnya lagi tentunya kita harus memperoleh suatu pengakuan terhadap ukuran kualifikasi dan kompetensi profesional yang membuat guru-guru Indonesia dapat meniti karir di berbagai negara. Oleh karena itu untuk siap menghadapi kondisi demikian, dirasa sangat penting untuk membangkitkan gairah dan motivasi mahasiswa khususnya calon guru untuk siap menghadapi era yang sedemikian. Mengidentifikasi dari awal kemampuan dasar matematis dengan berbagai pendekatan yang berbeda-beda menjadi tolak ukur dosen dalam mempersiapkan mahasiswa nya sendiri untuk menguasai bidang nya demi mencapai kompetensi yang profesional sesuai dengan ilmu yang dimilikinya.

Penelitian ini menitik beratkan tentang hubungan pendekatan pembelajaran dan hasil matematika yang di ukur dari korelasi antara hasil belajar matematika dengan pendekatan pembelajaran atau metode belajar. Meskipun demikian, penelitian ini tidak secara khusus mengukur tipe kemampuan individu dengan pendekatan belajar yang spesifik dalam hubungan nya dengan kemampuan dasar matematika. Sehingga, tujuan dari penelitian ini adalah untuk menganalisa perbedaan kemampuan dasar matematika mahasiswa berdasarkan pendekatan pembelajaran yang berbeda. Maka dua pertanyaan berikut akan menjadi titik fokus dalam penelitian ini 1)Berapa klaster pendekatan belajar yang dimiliki dalam pembelajaran di program studi pendidikan matematika 2) Apakah kemampuan dasar matematika diantara mahasiswa berbeda secara signifikan melalui pendekatan pembelajaran yang berbeda.

\section{Metode Penelitian}

Populasi dalam penelitian ini adalah seluruh mahasiswa program studi Matematika Fakultas Keguruan dan Ilmu Pendidikan (FKIP) Universitas HKBP Nommensen, sedangkan sampel nya adalah mahasiswa program studi matematika 
semester 2. Metode pengambilan sampel dengan metode klaster.

Untuk mengukur kemampuan dasar matematika digunakan 5 dari 15 item klasifikasi keberhasilan kemampuan matematika berdasarkan statistik kelas bisnis menurut Johnson dan Kuennen (2006). Untuk mengukur pendekatan pembelajaran mahasiswa digunakan daftar skala ASSIST. Skala ASSIST mempunyai 3 faktor dan masing-masing faktor memiliki 6 item dengan 5 poin skala Likert ( $1=$ tidak setuju sampai dengan 5 = sangat setuju ). Jumlah masing-masing faktor mengukur besarnya nilai pendekatan strategi, dalam, luaran. Koefisien realibilitas alpha 0,67 ; 0,51; 0,062 masing-masing untuk strategi, dalam dan luaran.

Analisis data dilakukan dengan dua tahap, langkah pertama dilakukan untuk menjawab pertanyaan pertama dan untuk menentukan jumlah pendekatan pembelajaran diantara mahasiswa atau jumlah grup yang dapat dibagi berdasarkan skala assist dengan menggunakan metode BIC (Bayesian Information Criterion). Kemudian, jumlah grup dengan menggunakan analisis klaster dua tahap dengan menggunakan kriteria maksimum likelihood dengan tujuan untuk mengklasifikasi mahasiswa kedalam grup dan untuk mengidentifikasi pendekatan pembelajaran. Setelah itu untuk menjawan pertanyaan kedua dilakukan langkah kedua, digunakan analisiss ANOVA satu arah dengan variabel terikat nya adalah kemampuan dasar matematis, dan variabel terikat nya adalah pendekatan belajar mahasiswa. Post Hoc tes dan Least Significant Differences (LSD) digunakan untuk melihat signifikansi perbedaan pendekatan pembelajaran berdasarkan kemampuan dasar matematisnya. Untuk menganalisa semua data digunakan software SPSS versi 13. 


\section{Hasil Dan PEMbahasan}

Dari hasil analisis data, maka tabel 1 diperoleh korelasi antara kemampuan dasar matematis dengan masing-masing sub skala pendekatan belajar skala ASSIST. Tabel 1 menjelaskan, kemampuan dasar matematis memiliki hubungan signifikansi negatif terhadap pendekatan belajar tipe permukaan dengan nilai $r=-0.23$ dan $\mathrm{p}<0.01$. Dengan kata lain, dengan adanya penurunan nilai dari pendekatan belajar tipe permukaan terdapat peningkatan kemampuan dasar matematis. Juga ditemukannya, hubungan secara langsung antara kemampuan dasar matematis dengan pendekatan belajar tipe mendalam, tetapi tidak signifikan dengan nilai $\mathrm{r}=$ $0.126, p>0.05$. Kemampuan dasar matematis memiliki hubungan signifikansi yang positif dengan pendekatan belajar tipe strategis dengan $r=0.226, p<0.01$. Analisis ini menjelaskan bahwa dengan meningkatnya pendekatan belajar tipe strategis maka kemampuan dasar matematis mahasiswa juga akan meningkat.

Tabel 1. Korelasi antara Kemampuan dasar matematis dengan sub skala ASSIST

\begin{tabular}{cccc}
\hline Pendekatan & $\mathbf{r}$ & P-value & $\mathbf{N}$ \\
\hline Permukaan & -0.23 & 0.007 & 118 \\
Strategis & 0.226 & 0.007 & 118 \\
Mendalam & 0.126 & 0.141 & 118 \\
\hline
\end{tabular}

Gambar 1 mengindikasikan hasil komputasi kriteria nilai BIC dengan masing-masing kluster. Grafik tersebut menggambarkan nilai klaster dari BIC terdapat pada angka terendah $3(\mathrm{BIC}=275.56)$. Oleh karena itu pertanyaan pertama pada rumusan masalah dalam penelitian ini telah dibuktikan, yaitu bahwa klaster dari skala ASSIST untuk pendekatan pembelajaran berada dalam 3 klaster. 


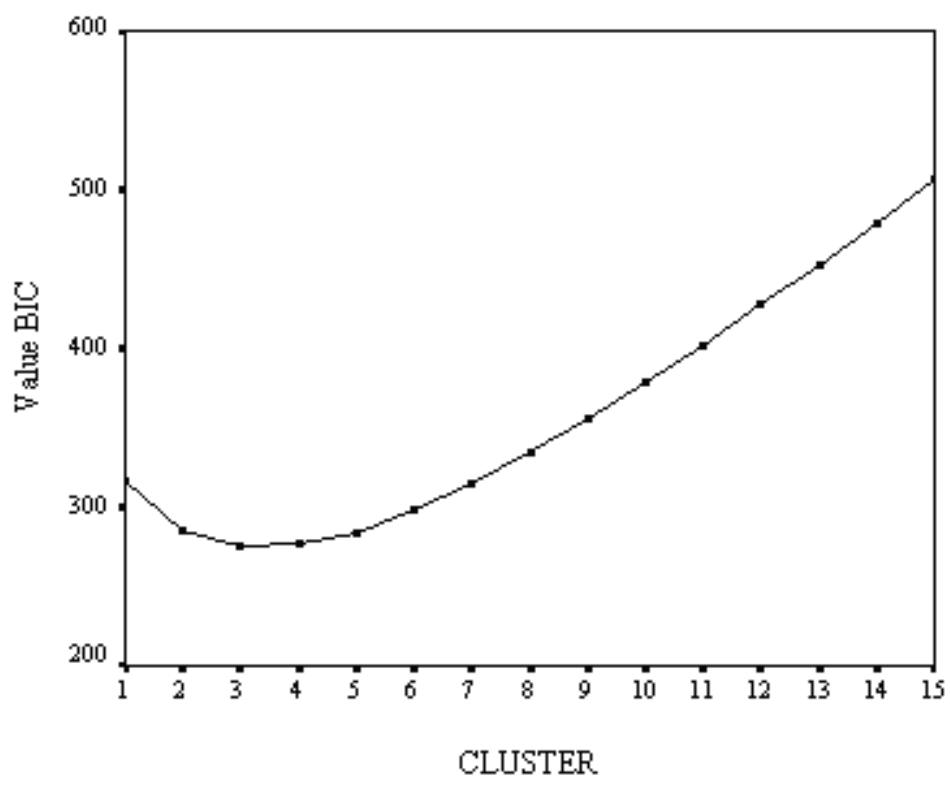

Gambar 1. Nilai kriteria BIC berdasarkan Klaster Skala ASSIST

Setelah menentukan nilai dari klaster, mahasiswa diklasifikasikan kedalam klaster-klaster melalui metode klaster dua tahap dan menggunakan kriteria dari maksimum likelihood. Untuk menentukan nama-nama klaster dan untuk mengidentifikasi pendekatan belajar mahasiswa maka dicarilah perbandingan ratarata dari klaster-klaster.

Tabel 2 memperlihatkan rata-rata dan standar deviasi dari tes kemampuan dasar matematis untuk masing-masing klaster dari pendekatan pembelajaran mahasiswa. Untuk melihat signifikansi perbedaan rata-rata dari kemampuan dasar matematis mahasiswa digunakan analisis ANOVA satu arah.

Tabel 2. Rata-rata dan standar deviasi kemampuan dasar matematis pada masing-masing klaster

\begin{tabular}{cccc}
\hline Pendekatan & Mendalam(n=39) & Strategis $(\mathbf{n = 4 0 )}$ & $\begin{array}{c}\text { Permukaan } \\
(\mathbf{n = 3 9 )}\end{array}$ \\
\hline Rata-rata & 10.51 & 8.91 & 8.24 \\
\hline SD & 2.93 & 3.29 & 3.73 \\
\hline
\end{tabular}

Tabel 3 menjelaskan pendekatan pembelajaran menjadi variabel bebas dan 
kemampuan dasar matematis merupakan variabel terikat. Dari hasil analisis nya menunjukkan rata-rata perbedaan kemampuan dasar matematis yang signifikan pada masing-masing pendektatan pembelajaran yang berbeda-beda. $(\mathrm{F}(2,136)=$ $5.6, \mathrm{p}<0.01)$

Tabel 3. ANOVA satu arah untuk variabel yang sempurna dalam kemampuan dasar matematis

\begin{tabular}{cccccc}
\hline Sumber & $\begin{array}{c}\text { Jumlah } \\
\text { Kuadrat }\end{array}$ & Df & $\begin{array}{c}\text { Rata-rata } \\
\text { kuadrat }\end{array}$ & F & $\begin{array}{c}\text { P- } \\
\text { value }\end{array}$ \\
\hline Antar Grup & 125.45 & 2 & 62.72 & 5.6 & 0.005 \\
Dalam Grup & 1523.71 & 115 & 11.2 & & \\
Total & 1649.16 & 117 & & & \\
\hline
\end{tabular}

Tabel 4 menjelaskan multi perbandingan dari rata-rata kemampuan dasar matematis dengan menggunakan metode LSD. Berdasarkan hasil analisis ini, tidak ada perbedaan yang signifikan antara pendekatan strategis dan pendekatan permukaan $(\mathrm{p}=0.339)$. Perbedaan rata-rata antara kemampuan dasar matematis dengan pendekatan Permukaan dan pendekatan mendalam adalah positif dan signifikan $(\mathrm{p}<0.01)$ dan antara pendekatan mendalam dan strategis positif dan signifikan $(\mathrm{p}<0.05)$. Oleh karena itu dapat disimpulkan mahasiswa dengan pendekatan mendalam memiliki dasar lebih tinggi daripada pendekatan strategis dan permukaan.

Tabel 4. Jumlah tes LSD untuk rata-rata kemampuan dasar matematis dengan pendekatan belajar.

\begin{tabular}{lllll}
\hline Pendekatan(I) & Pendekatan(J) & $\begin{array}{c}\text { Rata-rata perbedaan } \\
(\mathrm{I}-\mathrm{J})\end{array}$ & Standar Error & P-value \\
\hline Strategis & Permukaan & 0.64 & 0.698 & 0.339 \\
Mendalam & Permukaan & 2.27 & 0.698 & 0.001 \\
Mendalam & Strategis & 1.60 & 0.690 & 0.022 \\
\hline
\end{tabular}

\section{KESIMPULAN}

Korelasi antara kemampuan dasar matematika mahasiswa dengan 
pendekatan belajar mengindikasikan bahwa kemampuan dasar matematis memiliki hubungan yang positif dengan pendekatan strategi dan hubungan yang signifikan terhadap pendekatan permukaan. Terdapat juga hubungan positif antara kemampuan dasar matematis dengan pendekatan mendalam walaupun tidak signifikan.

Dengan mempertimbangkan analisis korelasi, semua variabel secara bersama-sama tidak berkontribusi terhadap tinggi rendahnya nilai mahasiswa sehingga analisis klasternya dengan mudah diklasifikasikan menjadi 3 grup. Analisis Anova satu arah dengan metode LSD menunjukkan bahwa mahasiswa dengan pendekatan belajar tipe mendalam memiliki kemampuan dasar paling tinggi dibanding dengan pendekatan strategi dan pendekatan permukaan.

Untuk mengukur kemampuan mahasiswa, seorang dosen harus mendisain nilai-nilai yang dapat memotivasi pemahaman, penilaian dan cara berfikir kritis mahasiswa sehingga mahasiswa dapat memahami konsep dan materi melalui pendekatan yang mendalam. Dosen juga berperan dalam membuat tugas mahasiswa yang didalamnya memuat aktivitas mental yang tinggi sehingga dalam mengerjakannya pun mereka benar-benar belajar

\section{Daftar Pustaka}

[1] Bassant, K. C. (1995). Factors associated with types of mathematics anxiety in college students. Journal of Research in Mathematics Education, 26, 327- 345.

[2] Biggs, J. (2003). Teaching for quality learning at university (2nd ed.). Berkshire, UK: Open University Press.

[3] Crawford, K., Gordon S., Nicholas, J. and Prosser, M. (1998). Qualitatively different experiences of learning mathematics at university, Learning and Instruction, 8(5), 455-468.

[4] Crawford, M., \& White, M. (1999). Strategies for mathematics: Teaching in context. Educational Leadership, 57(3), 34-38.

[5] Dansereau, D. F., Collins, K. W., McDonald, B. A., Holley, C. D., Garland, J. C.,Diekhoff, G., \& Evans, S. H. (1979). Development and evaluation of a learning strategy program. Journal of Educational Psychology, 71, 64-73.

[6] Diseth, A., \& Martinsen, O. (2003). Approaches to learning, cognitive styles, and motives as predictors of academic achievement. Educational Psychology, 23, 195207. 
[7] Entwistle, N. (2008) Taking stock: teaching and learning research in higher education. Review prepared for an international symposium on "Teaching and Learning Research in Higher Education",Guelph, Ontario, April, 25-26, 2008.

[8] Jhonson, M., Kuennen, E.,(2006). Basic Math Skills and Performance in an Introductory Statistics Course. Journal of Statistics Education ,14(2), Retrieved June 11, 2009, from www.amstat.org/publications/jse/v14n2/johnson.html.

[9] Ma, X. (1996). The effects of cooperative homework on mathematics achievement of Chinese high school students. Educational Studies in Mathematics, 31, 379-387.

[10] Ma, X. (1999). A meta-analysis of the relationship between anxiety toward mathematics and achievement in mathematics. Journal for research in mathematics education, 30(5):520-540.

[11] McCoy, L. (1992). Correlates of mathematics anxiety. Focus on Learning Problems in Mathematics, 14(2), 51-57.

[12] Saif, A., A.(2007). Modern Educational Psychology: Psychology of Learning and Instruction. (6 rd ed.).Tehran: Dowran (In Persian).

[13] Steen, L., A.,(1989). Teaching Mathematics for Tomorrow's World. Educational Leadership, 47(1), 18-22

[14] Soemamrmo,U.,\&Hendriana, H. (2014). Penilaian Pembelajaran Matematika. Bandung: Refika Aditama. 